\title{
A Systems Thinking approach for responding to the COVID-19 pandemic
}

Imad Hassan, ${ }^{1}$ Fatima Obaid, ${ }^{1}$ Roa Ahmed, ${ }^{1}$ Lobna Abdelrahman, ${ }^{1}$ Sara Adam, ${ }^{1}$ Omiema Adam, ${ }^{1}$ Mohammed Alfatih Yousif, ${ }^{1}$ Khobieb Mohammed ${ }^{1}$ and Tayseer Kashif ${ }^{1}$

${ }^{1} \mathrm{Al}$ Tababa Knowledge Translation Unit, Al Tababa Advanced Training Center, Khartoum, Sudan. (Correspondence to: Imad Hassan: imadsahassan@yahoo.co.uk).

Citation: Hassan I; Obaid F; Ahmed R; Abdelrahman L; Adam S; Adam O; et al. A Systems Thinking approach for responding to the COVID-19 pandemic. East Mediterr Health J. 2020;26(8):872-876. https://doi.org/10.26719/emhj.20.090

Received: 07/05/20; accepted: 06/07/20

Copyright (c) World Health Organization (WHO) 2020. Open Access. Some rights reserved. This work is available under the CC BY-NC-SA 3.o IGO

license (https://creativecommons.org/licenses/by-nc-sa/3.o/igo)

\section{Introduction}

The human, social and economic costs of the COVID-19 pandemic are enormous. It is paramount that effective control strategies are implemented especially in resource-poor countries to initially mitigate and finally control this novel infection. Systems Thinking is considered a paradigm shift in human thinking. It first appeared in the business and management arena but has spread to all disciplines or 'systems', especially when the human factor is a pivotal element, e.g., in social systems. It was first publicized by a Nobel prize winner, Professor Peter Senge in his book, "The Fifth Discipline" (1).

The World Health Organization (WHO) has in a recent landmark publication, as well as among some international experts, strongly advocated the employment of a 'Systems Thinking' approach in formulating plans for resolving complex social and health issues (2); this includes the fight against COVID-19 (3). Systems thinking is an indispensable tool for quality improvement (4) and has shown promise in the fight against Human Immunodeficiency Virus infection and Hepatitis C (5).

\section{Understanding the concept}

A system is defined as an entity with interrelated and interdependent parts that are working together to achieve a common purpose; health care is considered a system. At its core is the concept of components interdependence at multiple levels. Any change in one part of the system affects the part and the whole system. Areas where system interventions produce higher impacts (using an equivalent input), are termed strong-leverage points.

The COVID-19 pandemic has so vividly brought this systems interconnectedness to the forefront of human thinking. As a health-care issue, the COVID-19 pandemic resulted in unprecedented impacts on all domains of life - economy, entertainment, transport, education etc. Additionally, it highlighted another critical domain in the Systems Thinking mindset - the domain of 'unintended consequences'. The latter will inevitably materialize as 'side-effects' to any intervention used to control the pandemic. Examples are the negative impacts of social distancing, curfew, market closures, etc. on people's livelihoods, mental health, domestic violence and other non-COVID-19 medical ailments (6-9).

\section{How to practice Systems Thinking?}

Systems Thinking is a holistic approach to better understanding of how the system elements interact with each other over time, the root-causes of system defects, and the right approach for a highly effective problem-solving intervention (strong leverage areas). Systems thinking facilitates an in-depth understanding of system dynamics. Its tools enable its users to re-design their systems, thereby radically creating the results they truly desire thanks to a methodology for identifying the root causes and critically selecting and focusing on the right 'strong-leverage areas'. There are 5 pivotal steps in Systems Thinking: 1) root cause analysis, 2) selection of and focusing on strong-leverage areas, 3) system design or redesign coupled with 4) measures to nullify the impact of any unintended consequences resulting from these interventions and 5) continuous learning and improvement from the whole exercise.

One simple tool for identifying and categorizing the root causes, thus pinpointing the leverage areas, is the Iceberg Tool (10). The latter stratifies the issue or problem under consideration and its root causes into 4 elements: 1) the event (the problem); 2) the underlying pattern (why it happened); 3) the structures directly responsible for the pattern; and 4) The underlying cultural and mental models that maintain these structures and facilitate the persistence of the problem. Figure 1 portrays the Iceberg Tool and Figure 2 the Populated Tool for the problem of the COVID-19 pandemic in a resource-poor country. Systemic structures and mental models are considered the 'strong-leverage points' that system leaders should focus on when dealing with complex social problems and conflicts. The significance and importance of focusing on interventions in the mental model domain were the motivators for a joint New York University and UNICEF initiative to design a course for a "strategic global behavioural communication intervention" to deal with infectious diseases epidemics (11).

Another Systems Thinking tool for depicting these strong-leverage areas, thus facilitating their incorporation as building-blocks for 'a highly effective system', is 
Figure 1 The Iceberg Tool: Below the water line, one can notice patterns of behaviour enforced by the structure of the system and sustained by mental models.

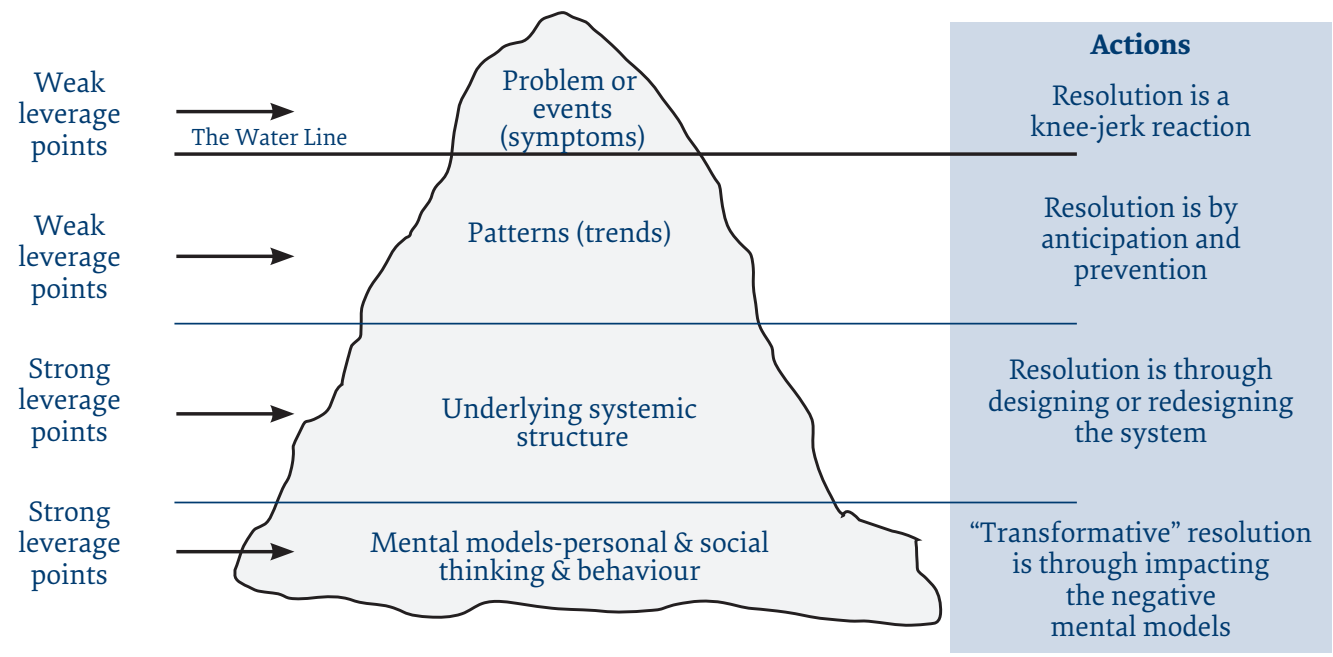

the Biomatrix Tool, which emanated from Biomatrix Systems Theory (12). Its seven components constitute the building blocks for any effective system. They are the pillars for any transformational project, whether it is a population-based or government intervention, organizational intervention, hospital, department or clinical unit intervention or establishment, etc. Unlike the classic description of a 'system' with only its 3 basic components (structure, process and outcome), the Biomatrix tool smartly incorporates 4 extra indispensable elements for comprehensive and successful system design or redesign. Thus, one may utilize it to build a comprehensive anti-COVID-19 system for fighting the pandemic.

Numerous interventions are recommended to prevent or slow the spread of COVID-19 infection (13-16). Table 1 depicts the seven elements, their definition and their relevant practical administrative components or actions for such a system. A major and deterministic 'leverage-point' for establishing this programme is purely administrative and falls squarely on government, professional and community leaders.

\section{The evidence that a System Approach works}

A recent Systematic Review (17), as well as experience from several countries that managed to mitigate COVID-19 infection employing elements in the System approach above, are worth referring to. Quarantine, especially if started early on and is combined with other system elements above, is very effective in reducing patient numbers and fatalities (17). South Korea applied a mitigation strategy thereby avoiding major social disruption actions, i.e., no true lockdown (18). Current daily figures for new infections hardly reach 50 to 100 cases.

Figure 2 The Iceberg Tool depicting the root causes of a failed response to a COVID-19 epidemic and the strong leverage points for effective action

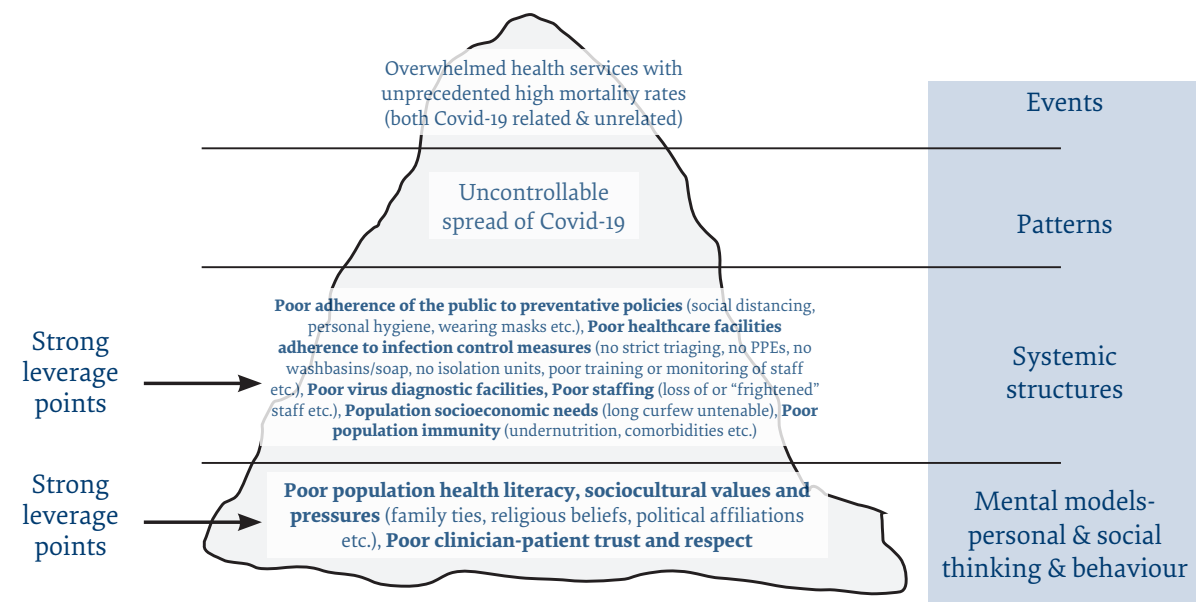




\section{Table 1 A COVID-19 control package using a Systems Thinking Biomatrix Tool and administrative actions}

\begin{tabular}{|c|c|c|c|}
\hline Biomatrix Item & Description & Component or Action & Examples \\
\hline Aims (Vision) & $\begin{array}{l}\text { The Outcome(s): the results that the } \\
\text { system wants to achieve. Aims create } \\
\text { focus. }\end{array}$ & $\begin{array}{l}\text { A nation without Coronavirus! } \\
\text { (Positive public Communication) }\end{array}$ & \\
\hline Ethos & $\begin{array}{l}\text { Organizational Culture: its unique } \\
\text { expectations, and values and is } \\
\text { expressed in its self-image: "As you } \\
\text { think, so you will become". }\end{array}$ & $\begin{array}{l}\text { We always win! } \\
\text { (Positive public Communication) }\end{array}$ & \\
\hline Structure & $\begin{array}{l}\text { The Organogram: the anatomy of a } \\
\text { system. }\end{array}$ & $\begin{array}{l}\text { Strategic Multidisciplinary, } \\
\text { Intergovernmental body with its } \\
\text { comprehensive administrative and } \\
\text { executive components. } \\
\text { - Strategic Roadmap for the Health- } \\
\text { care sector and the population as a } \\
\text { whole. } \\
\text { Monitoring and Assessment unit } \\
\text { with timely data capture, analysis } \\
\text { and action supported by efficient } \\
\text { information technology platforms. }\end{array}$ & $\begin{array}{l}\text { Multidisciplinary Team from } \\
\text { all ministries, nongovernmental } \\
\text { organizations, social support societies, } \\
\text { charitable organizations, professional } \\
\text { unions, international agencies etc. }\end{array}$ \\
\hline \multirow[t]{2}{*}{ Process } & $\begin{array}{l}\text { The Activities: describes the activities } \\
\text { of the system: the activities involved } \\
\text { in the delivery of services (training) to } \\
\text { the customers. }\end{array}$ & $\begin{array}{l}\text { Health care directed: } \\
\text { - Facility preparedness } \\
\text { - Staff education and training } \\
\text { - Confirmed and suspected patients' } \\
\text { clinical management pathways } \\
\text { - Staff support and incentives, etc. } \\
\text { - Patient and family education }\end{array}$ & $\begin{array}{l}\text { - Efficient screening of staff and } \\
\text { patients } \\
\text { - Effective diagnostic capabilities } \\
\text { - Reducing in-hospital transmission } \\
\text { (personal protective equipment } \\
\text { (PPEs), handwashing, triaging, } \\
\text { cohorting of patients and of staff, } \\
\text { disposal of hazardous material, } \\
\text { environmental cleanliness and } \\
\text { hygiene, restricting non-urgent } \\
\text { clinical services, virtual outpatient } \\
\text { and inpatient patient encounters, } \\
\text { etc.) } \\
\text { - Screening of visitors and restricting } \\
\text { hospitalized patients visits by } \\
\text { relatives, friends, etc. }\end{array}$ \\
\hline & & $\begin{array}{l}\text { Population Directed: Education } \\
\text { and empowerment, Personal } \\
\text { hygiene practices e.g. hand } \\
\text { washing, sneezing and coughing } \\
\text { etiquette etc., Social Distancing, } \\
\text { Wearing masks, Restriction of } \\
\text { social gathering e.g. at work, } \\
\text { schools, sporting events/social } \\
\text { events, Robust contact tracing and } \\
\text { isolation, Augmenting population } \\
\text { innate immunity: e.g. education } \\
\text { on healthy foods and herbs rich in } \\
\text { immunopotentiators etc. }\end{array}$ & $\begin{array}{l}\text { - Quarantine and isolation centers } \\
\text { Robust contact tracing, isolation } \\
\text { and close monitoring during } \\
\text { isolation etc. }\end{array}$ \\
\hline Resources & $\begin{array}{l}\text { Material and Intellectual Assets: } \\
\text { refer to the resources of the } \\
\text { organization, such as its capital } \\
\text { equipment, financial resources, } \\
\text { intellectual property, staff capabilities } \\
\text { etc. }\end{array}$ & $\begin{array}{l}\text { - System Leadership } \\
\text { - Diagnostic and treatment facilities } \\
\text { - Internists } \\
\text { - Infection Control Specialists } \\
\text { - Patient Educators } \\
\text { - Epidemiologists } \\
\text { - Infectious Diseases Specialists } \\
\text { - Intensivists } \\
\text { - Trainers and Educationalists } \\
\text { - Statisticians } \\
\text { - Financial Resources } \\
\text { - Monitoring teams/IT Specialists } \\
\text { - Social Psychologists } \\
\text { - Audiovisual Resources } \\
\text { - Covid-19 cyberspace resources, } \\
\text { Website, Blogs in simple language } \\
\text { - etc. } \\
\text { - Local Social and Religious support } \\
\text { teams }\end{array}$ & \\
\hline
\end{tabular}




\begin{tabular}{|c|c|c|c|}
\hline Biomatrix Item & Description & Component or Action & Examples \\
\hline Environment & $\begin{array}{l}\text { Local \& Surrounding Facilitators } \\
\text { \& Barriers: (the latter need to be } \\
\text { resolved at the outset). }\end{array}$ & $\begin{array}{l}\text { Social activists and local support } \\
\text { networks in the community. } \\
\text { - Incentive Program for all healthcare } \\
\text { workers. } \\
\text { - Insurance and financial support } \\
\text { to healthcare workers who get } \\
\text { infected. } \\
\text { - Collaboration with Research } \\
\text { Centers, Technology and } \\
\text { Innovation Centers, Evidence- } \\
\text { based Practice Centers, Quality } \\
\text { Improvement Organizations, } \\
\text { International bodies etc. }\end{array}$ & \\
\hline Governance & $\begin{array}{l}\text { Regulation \& Monitoring: The } \\
\text { function of governance in an } \\
\text { organization is to set aims and to } \\
\text { monitor and regulate the movement } \\
\text { of the organization towards the } \\
\text { attainment of these aims. }\end{array}$ & $\begin{array}{l}\text { Daily reporting from the } \\
\text { monitoring unit and assessment } \\
\text { of progress, successes and failures } \\
\text { and timely interventions to } \\
\text { improve performance and deal with } \\
\text { unintended consequences. }\end{array}$ & \\
\hline
\end{tabular}

On the other hand, New Zealand and Jordon applied both mitigation and suppression measures with significant population-based lockdown strategies (19-20). Their current daily figures are less than 10 cases. All three countries employed thorough screening and diagnostic methods, contact tracing, isolation, and reporting of cases. These were coupled with robust organizational capabilities, electronic tracing, education, monitoring, positive public health communication, and involvement governed and monitored by high-level administrative structures $(18-20)$. However, better outcomes in the latter two countries are primarily due to employment of all system elements. A recent review exploring the elements and measures in many countries supports this Systems Thinking approach (21).

\section{References}

1. Senge, P. The fifth discipline: The art and practice of the learning organizations. New York: Doubleday. (1990).

2. De Savigny D, Taghreed A, Alliance for Health Policy and Systems Research, World Health Organization. Systems thinking for health systems strengthening. Geneva: Health Organization; 1990 (https://www.who.int/alliance-hpsr/resources/9789241563895/en/).

3. Bradley DT, Mansouri MA, Kee F, Garcia LMT. A systems approach to preventing and responding to COVID-19. EClinicalMedicine. 2020:100325. doi: 10.1016/j.eclinm.2020.100325 (https://www.ncbi.nlm.nih.gov/pmc/articles/PMC7118639/).

4. Tello JE, Barbazza E, Waddell K. Review of 128 quality of care mechanisms: A framework and mapping for health system stewards. Health Policy. 2020;124(1):12-24. doi: 10.1016/j.healthpol.2019.11.006 (https://www.ncbi.nlm.nih.gov/pmc/articles/ PMC6946442/).

5. Brown G, Reeders D., Cogle A., Madden A., Kim J, O’Donnell D. A Systems thinking approach to understanding and demonstrating the role of peer-Led programs and leadership in the response to HIV and Hepatitis C: Findings From the W3 Project. Front Public Health. 2018;6:231. doi: 10.3389/fpubh.2018.00231 (https://www.ncbi.nlm.nih.gov/pmc/articles/PMC6127267/pdf/ fpubh-06-00231.pdf).

6. Garfin DR, Silver RC, Holman EA. The novel coronavirus (COVID-2019) outbreak: amplification of public health consequences by media exposure. Health Psychol. 2020 May;39(5):355-357. doi: 10.1037/hea0000875. (https://psycnet.apa.org/fullh text/2020-20168-001.pdf)

7. Choi KR, Heilemann MV, Fauer A, Mead M. A second pandemic: mental health spillover from the novel coronavirus (COVID-19). J Am Psychiatr Nurses Assoc. 2020 Apr 27:1078390320919803. doi: 10.1177/1078390320919803. (https://journals.sagepub.com/doi/ pdf/10.1177/1078390320919803)

8. Chakraborty I, Maity P. COVID-19 outbreak: migration, effects on society, global environment and prevention. Sci Total Environ. 2020 Apr 22;728:138882. doi: 10.1016/j.scitotenv.2020. (https://www.ncbi.nlm.nih.gov/pmc/articles/PMC7175860/pdf/main. pdf).

9. John N, Casey SE, Carino G, McGovern T. Lessons never learned: crisis and gender-based violence. Dev World Bioeth. 2020 Apr 8. doi: 0.1111/dewb.12261. (https://onlinelibrary.wiley.com/doi/epdf/10.1111/dewb.12261).

10. Maani K, Cavana R. Systems Thinking and Modelling: understanding change and complexity. Auckland: Pearson; 200o. (https:// pdfs.semanticscholar.org/235c/oec4b99a770ab13a28bod5ebe0752e7fbc55.pdf). 
11. Dickey C, Holzman E, Bedford J, Manoncourt E, Shirky C, Petit V, et al. Behavioral communication strategies for global epidemics: an Innovative model for public health education and humanitarian response. Health Promot Pract. 2020:1524839920916465. doi: 10.1177/1524839920916465. (https://journals.sagepub.com/doi/pdf/10.1177/1524839920916465)

12. Systemic organizational development: Application of biomatrix systems theory to organizational development. Available online Biomatrix Web (http://biomatrixweb.com/organisational-development/).

13. World Health Organization. Country \& technical guidance - Coronavirus disease (COVID-19). Geneva: World Health Organization; 2019 (https://www.who.int/emergencies/diseases/novel-coronavirus-2019/technical-guidance)

14. Lai S, Ruktanonchai NW, Zhou L, Prosper O, Luo W, Floyd JR, et al. Effect of non-pharmaceutical interventions to contain COVID-19 in China. Nature. 2020. doi: 10.1038/s41586-020-2293-x. (https://www.nature.com/articles/s41586-020-2293-x_reference. pdf) (accelerated article peer review)

15. Nussbaumer-Streit B, Mayr V, Dobrescu AI, Chapman A, Persad E, Klerings I, et al. Quarantine alone or in combination with other public health measures to control COVID-19: a rapid review. Cochrane Database Syst Rev. 2020;4:CDo13574. doi: 10.1002/14651858.CD013574. (https://www.cochranelibrary.com/cdsr/doi/10.1002/14651858.CDo13574/full)

16. Pan A, Liu L, Wang C, Guo H, Hao X, Wang Q, et al. Association of public health interventions with the epidemiology of the COVID-19 outbreak in Wuhan, China. JAMA. 2020. doi: 10.1001/jama.2020.6130. (https://jamanetwork.com/journals/jama/fullar: ticle/2764658)

17. Nussbaumer-Streit B, Mayr V, Dobrescu AL, Chapman A, Persad E, Klerings I, et al. Quarantine alone or in combination with other public health measures to control COVID-19: a rapid review. Cochrane Database Syst Rev. 2020. (https://www.cochranelie brary.com/cdsr/doi/10.1002/14651858.CDo13574/full)

18. Choi H, Cho W, Kim MH, Hur JY. Public health emergency and crisis management: case study of SARS-CoV-2 outbreak. Int J Environ Res Public Health. 2020 Jun 4;17(11):E3984. doi: 10.3390/ijerph17113984 (https://www.mdpi.com/1660-4601/17/11/3984)

19. Cousins S. New Zealand eliminates COVID-19. Lancet. 2020;395(10235):1474. (https://www.ncbi.nlm.nih.gov/pmc/articles/ PMC7190497/pdf/main.pdf)

20. Al-Tammemi AB. The battle against COVID-19 in Jordan: an early overview of the Jordanian experience. Front Public Health 2020;8:188. doi: 10.3389/fpubh.2020.00188. (https:/www.ncbi.nlm.nih.gov/pmc/articles/PMC7220996/pdf/fpubh-08-00188.pdf)

21. Patiño-Lugo DF, Velez M, Salazar PV, Vera-Giraldo CY, Vélez V, Marín IC, et al. Non-pharmaceutical interventions for containment, mitigation and suppression of COVID-19 infection. Colombia Médica: Vol 51 No 2 (2020): Coronavirus disease 2019. (https://colombiamedica.univalle.edu.co/index.php/comedica/article/view/426/4771) 